\title{
Qualitative Study Of Complementary Feeding For Stunting Toddlers Aged 13-24 Months In Cipadang Village, Pesawaran District
}

\author{
Sutrio, Dewi Sri Sumardilah \\ Politeknik Kesehatan Tanjung Karang \\ Emailsutrio.syakir@yahoo.com
}

\begin{tabular}{l} 
Article Info \\
Article history \\
Received date: $2020-05-29$ \\
Revised date: $2020-06-03$ \\
Accepted date: $2020-07-27$ \\
\hline
\end{tabular}

\begin{abstract}
Stunting children are the result of chronic nutritional problems as a result of food quality, coupled with morbidity, infectious diseases and environmental problems. This study aims to determine the description of complementary feeding practice for stunting toddlers aged 13-24 months in Cipadang village. This study uses a qualitative approach conducted by conducting in-depth interviews and observations. The informants in this study were the main caregivers of toddlers's mother, family informants and health center nutrition workers. The results of the study showed that the parenting of breastfeeding complementary feeding was still less than the variation, portion and frequency of its giving. Mother or caregivers are encouraged to regularly come to the posyandu and ask cadres or health workers about the provision of good complementary feeding for stunting toddlers, especially in terms of portions, frequency and variation. In addition health workers must always provide assistance to stunting toddlers in order to get the optimal health degree.

Keywords:

Complementary feeding Practice, Toddlers'Stunting
\end{abstract}

\begin{abstract}
Abstrak
Stunting merupakan masalah gizi kronis sebagai akibat makanan yang tidak berkualitas, ditambah dengan morbiditas, penyakit infeksi dan masalah lingkungan. Penelitian ini bertujuan untuk mengetahui pemberian Makanan Pendamping Asi pada baduta stunting usia 13-24 bulan di desa Cipadang. Penelitian ini menggunakan pendekatan kualitatif yang dilakukan dengan melakukan wawancara mendalam dan observasi. Informan dalam penelitian ini adalah pengasuh utama ibu baduta, informan keluarga dan tenaga gizi puskesmas. Hasil penelitian bahwa pola asuh pemberian makanan pendamping ASI masih kurang dari variasi, porsi dan frekuensi pemberiannya. Peran aktif ibu atau pengasuh sangat dibutuhkan dalam pemberian makan kepada anak. lbu atau pengasuh dianjurkan untuk rutin datang ke posyandu dan menanyakan kepada kader ataupun petugas kesehatan tentang pemberian MP-ASI yang baik untuk anak terutama dari segi porsi, frekuensi dan variasi. Selain itu petugas kesehatan harus selalu melakukan pendampingan pada balita stunting agar dapat mendapatkan derajad kesehatan yang optimal.

Kata Kunci

Praktik Pemberian MP ASI, Balita Stunting
\end{abstract}

\section{PENDAHULUAN}

Stunting menggambarkan status kurang gizi yang bersifat kronik pada masa pertumbuhan dan perkembangan sejak awal kehidupan dan merupakan bentuk gangguan pertumbuhan linear yang terjadi terutama pada anak-anak. Anak yang stunting merupakan hasil dari masalah gizi kronis sebagai akibat makanan yang tidak berkualitas, ditambah dengan morbiditas, penyakit infeksi dan masalah lingkungan. Dengan kata lain stunting dapat diketahui bila seorang balita 
yang sudah diketahui umurnya dan diukur panjang atau tinggi badannya, lalu dibandingkan dengan standar, dan hasilnya berada dibawah normal. Jadi secara fisik balita lebih pendek dibandingkan balita seumurnya [1].

Secara global, Stunting merupakan masalah kesehatan masyarakat utama. sekitar 1 dari 4 balita mengalami stunting dan masih menjadi masalah gizi masyarakat baik di tingkat nasional dan internasional [2]. Di Indonesia, berdasarkan hasil Riset Kesehatan Dasar 2013 prevalensi stunting di tingkat nasional mencapai $37,2 \%$ dan angka itu lebih tinggi dibandingkan stunting negara-negara di Asia Tenggara seperti Myanmar $(35 \%)$, Vietnam (23\%) dan Thailand (16\%) [3]. Pada tingkat provinsi, prevalensi stunting Provinsi Lampung menempati urutan keenam tertinggi di Indonesia yaitu sebesar $42,6 \%$ [4]. Pada tingkat kabupaten, berdasarkan Buku Saku PSG 2017 prevalensi stunting di kabupaten Pesawaran sebesar 35,1\% tertinggi nomor 4 setelah kabupaten Lampung Barat, Tanggamus dan Lampung Tengah.

Pola asuh merupakan salah satu faktor yang berkaitan dengan stunting. Penelitian Picauly dan Toy (2013), menunjukkan bahwa ibu dengan pola asuh yang kurang atau rendah memiliki peluang besar anaknya terkena stunting dibandingkan ibu dengan pola asuh baik. Peran ibu dalam pengasuhan sangat penting karena merupakan orang terdekat kepada anak. Pemberian makan ibu dapat mempengaruhi tumbuh kembang anak secara positif maupun negatif [5].

Peranan karakteristik ibu dan pola asuh sangat menentukan pengaruhnya terhadap status gizi balita [6]. Umumnya orang tua memberikan makanan yang kurang teratur dan terkadang memaksakan suatu makanan kepada anak. Selain itu tidak ada usaha dari keluarga agar anak mau makan dan lebih membiarkan anak jajan sembarangan (Lubis, 2010) [7]. Sebagian besar ibu berperilaku kurang seperti memberikan bentuk makanan, frekuensi pemberian makanan yang kurang dari usia balita dan adanya anak usia 1 bulan yang diberikan nasi.

Pola asuh pemberian makan yang diterapkan juga kurang baik dan tidak memenuhi gizi. Biasanya anak hanya diberikan makanan yang kurang bervariasi dan hampir sama setiap harinya serta porsi kurang. Makanan yang diberikan berupa nasi, tim atau bubur dengan kuah sayur atau bumbu saja seperti kecap dan garam serta anaknya jarang diberikan sayur dan buah (Veriyal, 2010) ${ }^{8}$. Padahal, masyarakat telah diberikan informasi bagaimana pola asuh makan yang baik, baik melalui penyuluhan ataupun klinik gizi melalui konseling. Tetapi karena kurangnya pemahaman dan pengetahuan yang dilatar belakangi pendidikan dan ekonomi yang rendah, keadaan tetap seperti itu dan sulit untuk merubahnya ${ }^{7}$.

Berdasarkan penelitian sebelumnya yang dilakukan di desa Cipadang dari 30,1\% batita memiliki status gizi pendek (Stunting). Berdasarkan hasil wawancara kepada TPG Puskesmas Gedong Tataan penyebab utama masalah gizi pada balita yaitu asupan makanan dan penyakit infeksi. Hal ini dapat dilihat dari rendahnya cakupan pemberian Asi ekslusif, praktik pemberian makanan yang kurang teratur, kurangnya keaktifan kunjungan ke posyandu.

\section{METODE}

Penelitian ini merupakan penelitian kualitatif menggunakan focus group discussion (FGD), wawancara mendalam dan observasi. Informan utama penelitian ini adalah ibu yang mengasuh dari baduta usia 13-24 bulan yang mengalami stunting, bukan karena penyakit atau cacat bawaan. Jumlah informan utama dalam penelitian ini ditetapkan 4 orang. Pemilihan 4 informan didasarkan pada rekomendasi yang diberikan Riemen (1986) dalam Creswell (1998) dalam Akhmadi (2009) yang merekomendasikan jumlah informan sebanyak 3-10 orang. Informan Pendukung 
dalam penelitian ini yaitu keluarga dari baduta yang mengalami stunting dan Tenaga Pelaksana Gizi Puskesmas [9].

Analisa data yang digunakan adalah analisis interaktif [10]. Analisis interaktif terdiri dari 3 alur kegiatan yang saling berhubungan, yaitu reduksi data, penyajian data dan penarikan kesimpulan.

\section{HASIL DAN PEMBAHASAN Hasil}

\section{A. Karakteristik Informan}

\section{Informan Utama}

Informan utama dalam penelitian ini adalah pengasuh utama dari baduta usia 13-24 bulan yang mengalami stunting, terdiri dari 4 informan. Keempat informan tersebut berasal dari desa cipadang. Berikut adalah karakteristik informan utama :

Tabel 1. Karakteristik Pengasuh Utama dari Baduta Usia 13-24 Bulan yang Mengalami Stunting

\begin{tabular}{|c|c|c|c|c|}
\hline $\begin{array}{l}\text { Baduta } \\
\text { Stunting }\end{array}$ & $R a$ & $A i$ & La & $A l$ \\
\hline $\begin{array}{l}\text { Umur Balita } \\
\text { (Bulan) }\end{array}$ & 13 & 18 & 20 & 24 \\
\hline $\begin{array}{l}\text { Jenis } \\
\text { Kelamin }\end{array}$ & $\operatorname{Pr}$ & $\operatorname{Pr}$ & $\operatorname{Pr}$ & $\operatorname{Pr}$ \\
\hline$T B(\mathrm{Cm})$ & 70 & 69.5 & 74.5 & 75 \\
\hline $\begin{array}{l}\text { BB Lahir } \\
\text { (gr) }\end{array}$ & 2.100 & 2.200 & 2.700 & 2.300 \\
\hline $\begin{array}{l}\text { Nama } \\
\text { Pengasuh } \\
\text { Utama }\end{array}$ & Sh & $\mathrm{Nh}$ & Yu & $Y$ \\
\hline $\begin{array}{l}\text { Umur } \\
\text { Pengasuh } \\
\text { Utama }\end{array}$ & 25 & 25 & - & 25 \\
\hline $\begin{array}{l}\text { Pendidikan } \\
\text { Pengasuh } \\
\text { Utama }\end{array}$ & SD & SD & SD & SMA \\
\hline $\begin{array}{l}\text { Pekerjaan } \\
\text { Pengasuh } \\
\text { Utama }\end{array}$ & IRT & IRT & IRT & IRT \\
\hline $\begin{array}{l}\text { Pekerjaan } \\
\text { Ayah Baduta }\end{array}$ & BB & $\mathrm{BH}$ & PS & PK \\
\hline $\begin{array}{l}\text { Rata- rata } \\
\text { Penghasilan }\end{array}$ & 800.000 & 900.000 & 1.200 .000 & 1.100 .000 \\
\hline
\end{tabular}

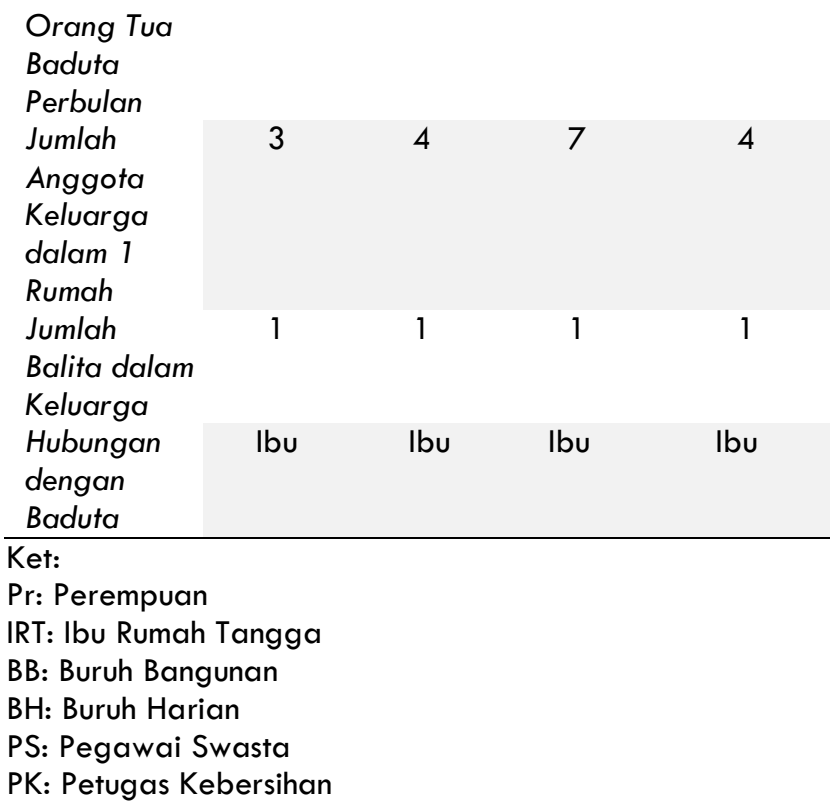

Berdasarkan tabel diatas diketahui bahwa seluruh baduta dalam penelitian ini memiliki jenis kelamin perempuan. Usia baduta yang paling kecil adalah 13 bulan dan paling besar berumur 24 bulan. Ketika lahir sebagian besar baduta tersebut memiliki berat badan di bawah 2.500 gram.

Sebagian besar umur informan utama berusi 25 tahun. separuh dari mereka mempunyai hubungan dengan anak sebagai ibu kandung sedangkan yang lainnya merupakan ibu angkat dan bibi dari baduta. Pekerjaan seluruh pengasuh utama dalam penelitian ini adalah ibu rumah tangga, sebagian besar dari mereka memilki tingkat pendidikan SD. Pekerjaan ayah baduta bervariasi mulai dari buruh bangunan sampai pegawai swasta. Semua orang tua baduta memilki pengasilan rendah. Dalam keluarga, seluruh informan memilki 1 orang balita dimana sebagian besar dari mereka memilki jumlah anggota keluarga kurang dari 5.

\section{Informan Pendukung}

a. Keluarga Baduta yang Mengalami Stunting

Informan keluarga baduta yang mengalami stunting terdiri dari 4 orang. Keempat 
informan tersebut adalah keluarga terdekat yang mengetahui pola asuh yang diterapkan pengasuh utama kepada anaknya. Berikut sedikit gambaran tentang informan pendukung yang berasal dari keluarga terdekat:

Tabel 2. Informan Pendukung Keluarga

\begin{tabular}{|c|c|c|c|c|}
\hline $\begin{array}{c}\text { Karakteristi } \\
\text { k }\end{array}$ & H/Sh & $\begin{array}{c}\text { Asm/ } \\
\text { Nh }\end{array}$ & $R h / Y u$ & $\mathbf{S} / \mathbf{Y}$ \\
\hline $\begin{array}{c}\text { Jenis } \\
\text { Kelamin } \\
\text { Pekeriaan }\end{array}$ & $\begin{array}{c}\text { LK } \\
\text { Buruh }\end{array}$ & $\begin{array}{l}\operatorname{Pr} \\
\text { IRT }\end{array}$ & $\begin{array}{l}\mathrm{Pr} \\
\text { IRT }\end{array}$ & $\mathrm{Pr}$ \\
\hline $\begin{array}{c}\text { Hubungan } \\
\text { dengan } \\
\text { Baduta } \\
\text { stunting }\end{array}$ & Ayah & Nenek & Bibi & Bibi \\
\hline $\begin{array}{l}\text { Ket: } \\
\text { Lk: Laki-laki } \\
\text { Pr: Perempuan } \\
\text { IRT: Ibu Rumah T } \\
\text { PK: Petugas Kel }\end{array}$ & $\begin{array}{l}\text { Tangga } \\
\text { Jersihan }\end{array}$ & & & \\
\hline
\end{tabular}

Berdasarkan tabel diatas diketahui bahwa sebagian besar jenis informan pendukung adalah perempuan. Separuh dari mereka adalah ibu rumah tangga.

b. Tenaga Pelaksana Gizi Puskesmas Informan pendukung lainnya adalah Tenaga Pelaksana Gizi Puskesmas Gedong Tataan sebanyak 1 orang.

\section{B. Pemberian Makanan Pendamping ASI}

Pola asuh pemberian makan dalam penelitian ini meliputi pemberian makanan selain ASI yang memperhatikan jumlah, frekuensi, dan variasi makanan untuk mencukupi kebutuhan gizi anak dengan tetap menjaga proses menyusui. Hasil penelitian mengenai praktik pemberian makanan tambahan didapatkan dari hasil wawancara mendalam kepada informan utama. Wawancara juga dilakukan kepada informan pendukung yang merupakan keluarga terdekat dan TPG Puskesmas Gedong Tataan. Selain itu,
Penggalian informasi juga dilakukan dengan cara observasi terhadap praktik pemberian makan yang dilakukan oleh informan utama ataupun informan pendukung.

Berdasarkan hasil wawancara yang dilakukan kepada informan utama, didapatkan hasil bahwa semua baduta yang mengalami stunting sudah diberikan nasi ketika umur anak sekitar 1 tahun. Selain nasi sebagai makanan pokok, anak juga lebih sering diberikan makan dengan 1 macam lauk dan sayur untuk setiap kali makan seperti telur yang dicampur dengan kecap, tahu, tempe, ikan, hati ampela, ataupun ayam. Untuk sayur yang diberikan, yang paling sering adalah sayur sop, kadang diberikan bayam, jagung, labu siam, kangkung, sampai sayur asam. Dalam hal pemberian sayur, ada anak yang memang memakan sayurnya dan ada pula anak yang hanya mau memakan kuahnya saja.

Berdasarkan hasil wawancara, diketahui bahwa seluruh informan masih memberikan susu kepada anak baik itu ASI ataupun susu formula bahkan ada 1 orang anak diberikan keduanya. Frekuensi pemberian ASI dan susu formula dalam penelitian ini mulai dari 2 sampai diatas 5 kali pemberian.

Ketika wawancara dengan salah satu informan pendukung didapat sedikit informasi yang mengatakan kalau anaknya sering diberikan nasi dengan sayur mayur saja tanpa tambahan lain. Berikut kutipannya:

Untuk pemberian buah, seluruh informan mengatakan kalau anak jarang diberikan buah, anak diberikan buah kalau memang sedang ada saja. Dari hasil wawancara, terdapat 1 informan yang mengaku bahwa anaknya tidak suka buah kecuali pepaya dan jeruk.

Berdasarkan hasil observasi didapatkan gambaran bahwa anak makan 2-3 kali dalam sehari. Terkadang 1 anak makan lebih 
dari 3 kali karena anak ikut kembali makan ketika ibu atau orang lain yang ada di rumah sedang makan. Ketika wawancara dengan pengasuh, momongan, ayah, dan ibu kandung didapatkan hasil bahwa anak memang suka ikut makan jika ada anggota keluarga yang makan. Berdasarkan hasil wawancara didapatkan informasi ada anak yang diberikan makan 2 kali perhari yaitu hanya pagi dan sore saja. Tetapi ketika wawancara dengan informan pendukung didapatkan hasil kalau anak kadang makan 3 kali sehari karena ditambahkan makan pada waktu siang.

Dalam hal Porsi, makanan pokok yang diberikan kepada anak seperti nasi, biasanya pengasuh utama memberikan antara 2 sampai 10 sendok makan ukuran sedang kepada baduta. Terdapat 3 baduta yang sulit untuk makan dan tidak dihabiskan. Sedangkan 1 baduta lainnya sangat menyukai makanan apa saja, untuk makanan pokok seperti nasi, biasanya baduta ini menghabiskan 1 centong atau lebih untuk setiap makannya.

Berdasarkan hasil wawancara kepada informan keluarga, didapatkan hasil yang sama mengenai porsi anak ketika makan.

Berdasarkan hasil observasi, lauk yang diberikan hanya 1 butir telur atau kurang, sepotong tahu, tempe, beberapa potong bakso, dan sedikit ikan atau ayam. Terkadang ada anak yang hanya diberikan nasi dan sayur saja tanpa tambahan lauk. Sebagaian besar anak terlihat tidak menghabiskan makanan yang diberikan dengan hanya beberapa suap saja kemudian meninggalkan makan yang diberikan atau tidak mau disuapi lagi.

Berdasarkan observasi juga didapatkan hasil bahwa ada anak yang pernah memakan mie instan dan ikut makan jika ada anggota keluarga lain yang makan, baik anak itu sedang berada di rumah ibu angkatnya ataupun ketika berada di rumah pengasuhnya. Selama observasi berlangsung, seluruh anak tidak pernah mengkonsumsi buah, hal ini sesuai dengan apa yang dikatakan oleh para informan utama bahwa anak diberikan buah jika memang sedang ada saja, waktunya tidak menentu, dan diberikan buah jika sedang ada penjual buah potongan yang berkeliling. Untuk sayur, porsi yang diberikan hanya sekitar 1-3 sendok makan seperti sayur sop, bayam, dan kangkung. Bahkan, ada anak yang susah untuk memakan sayur dan hanya mau diberikan kuahnya saja. Berdasarkan observasi juga terlihat 2 anak jarang diberikan sayur, hanya makanan pokok seperti nasi dan lauk saja, sedangkan susu diberikan jika anak mau atau ada waktu khusus seperti pagi dan sore hari.

Untuk makanan selingan, Berdasarkan hasil observasi didapatkan gambaran bahwa anak tidak diberikan makanan selingan. Biasanya anak dibuatkan susu ketika siang hari, bahkan ada anak yang diberikan dot susu agar anak tertidur pada siang hari. Ketika wawancara kepada informan utama didapatkan hasil yang sama dimana anak hanya diberikan makanan selingan berupa roti, itupun kalau anak sedang mau saja. Namun, terdapat perbedaan hasil observasi dengan wawancara kepada informan utama lainnya.

Hasil wawancara menyebutkan Anak diberikan makanan selingan biasanya berupa roti, wafer, dan biskuit.

Untuk masalah jajan, ketika observasi berlangsung, peneliti jarang melihat anak jajan, hanya melihat sekali sampai dua kali saja. Hal ini karena anak lebih senang bermain dengan teman- temannya diluar rumah, namun terkadang anak tersebut diberikan makanan seperti permen oleh teman-temannya karena kurang pengawasan dari orang tua. Ada anak masih terlalu kecil, sehingga jarang meminta jajan dan hanya menyusu saja atau main di depan rumah. Selain itu, ada 1 anak yang lebih sering menangis dan mau dengan ibunya saja 
karena takut dengan kedatangan peneliti. Tetapi peneliti juga pernah melihat anak diberikan makanan dari penjual keliling seperti cilok oleh ibunya. Peneliti juga pernah melihat 1 anak jajan es dan sejenis kerupuk berbumbu tetapi pengasuhnya hanya diam saja.

Berdasarkan hasil wawancara, didapatkan hasil bahwa anak memiliki kebiasaan jajan. Makanan yang sering dibeli anak yaitu permen, es, chiki, wafer, roti, dan biskuit. Mengenai seringnya anak jajan, informan mengatakan kalau anak jajan terkadang saja dan selalu diawasi, seperti dilarang beli chiki, permen, dan es. Namun terkadang juga ibu menuruti keinginan anak karena anak menangis.

Perilaku pemberian makan merupakan salah satu pola asuh yang menjadi masalah di wilayah kerja Gedong Tataan. Berdasarakan hasil wawancara kepada TPG puskesmas didapatkan informasi bahwa pemberian makan anak tidak sesuai dengan jumlah, jadwal, dan jenis. Porsi makan yang diberikan anak kurang dimana hanya separuhnya saja yang dimakan. Jadwal pemberian makan merupakan hal yang paling susah diterapkan oleh ibu karena tidak menyiapkan makan untuk anak. Ketika anak menagis dan tidak ada makanan, anak diberikan jajan yang macam-macam, akibatnya anak tidak mau makan lagi karena merasa sudah kenyang. Selain dua masalah diatas, variasi pemberian makan juga kurang dimana makanan yang diberikan hanya ituitu saja sehingga anak bosan dan tidak mau makan.

\section{Pembahasan}

Berdasarkan hasil wawancara kepada informan utama didapatkan gambaran bahwa makanan yang biasanya diberikan berasal dari bahan pokok, sayur dan laukpauk, untuk buah anak jarang diberikan. Namun berdasarkan hasil wawancara, pula didapatkan hasil bahwa anak lebih sering dengan satu jenis makanan saja seperti nasi dan telur. Berdasarkah hasil observasi memang benar anak lebih sering makan dengan nasi ditambah lauk pauk seperti tahu, tempe, telur ataupun ikan.

Penelitian Makmur (2008) memiliki kesamaan dengan penelitian ini dimana bahan makanan yang sering dibeli oleh ibu adalah sayur-sayuran, tempe, dan tahu. Untuk ayam, daging, dan ikan masih dianggap mahal [1 1 ]. Untuk tumbuh dan berkembang, balita membutuhkan enam zat gizi utama, yaitu karbohidrat, protein, lemak, vitamin, mineral, dan air. Keenam zat gizi tersebut dapat diperoleh dari makanan sehari- hari. Agar balita dapat tumbuh dan berkembang dengan baik, makanan yang dimakan tidak boleh hanya mengenyangkan perut saja. Dalam pemberian makan kepada balita seorang ibu atau pengasuh perlu melakukan pengaturan agar semua zat gizi diatas terdapat dalam menu sehari [12]. Menu dapat dibuat dengan siklus 10 hari untuk menghindari kebosanan pada anak dalam mengatasi kesulitan makan. Menu disusun dengan mengacu pada ketentuan syarat diet untuk anak balita, yaitu dapat memenuhi untuk pertumbuhan dan perkembangan, pemeliharaan badan, dan dapat menghasilkan kalori atau dengan kata lain cukup kualitas dan kuantitasnya [13].

Pengetahuan ibu mengenai makanan yang baik untuk anak sudah bagus. Hal ini didasarkan pada hasil wawancara dimana semua ibu menyebutkan bahwa makanan anak yang baik itu terdiri dari sayur, buah, ikan, dan nasi, bahkan ada 1 ibu yang mengatakan 4 sehat 5 sempurna. Tetapi dalam praktik sehari hari pemberian makan anak kadang hanya dengan nasi ditambah lauk atau nasi dengan sayur saja. Keadaan seperti ini dimungkinkan karena faktor ekonomi keluarga yang tergolong rendah, dimana kadang anak makan seadanya saja. Hal ini diperoleh dari hasil wawancara mendalam kepada informan utama, informan 
keluarga dan TPG setempat yang mengatakan bahwa faktor ekonomi merupakan hal yang sangat berpengaruh terhadap kebiasaan makan sehari-hari.

Frekuensi pemberian makan anak dalam penelitian masih kurang baik, dimana semua anak makan 3 kali perhari. Padahal menurut UNICEF pemberian makanan tambahan untuk anak usia 12-24 bulan adalah 5 kali perhari. Sedangkan menurut Soetardjo (2011) [14], memberikan makan anak 5 sampai 6 kali perhari lebih baik karena balita mempunyai perut yang kecil. Anak yang makan kurang dari 4 kali perhari, memiliki asupan zat gizi yang lebih sedikit dibandingkan rata-rata anak lain yang makan 4 kali sehari atau lebih. Namun berdasarkan hasil wawancara terdapat anak yang terkadang makan 2 kali perhari karena anak sudah kenyang dengan susu. Kemudian ada pula anak yang makan lebih dari 3 kali perhari karena ketika bapak atau kakaknya makan anak ikut kembali makan. Untuk anak ini, berdasarkan pengakuan dari ibu kandung, ibu angkat, dan pengasuhnya memang sangat suka makan apa saja dan sering ikut makan ketika ada saudara yang makan.

Penelitian Veriyal (2010) [8], mengambarkan hal yang lebih tidak baik dalam frekuensi makan kepada anak. Dalam penelitian itu disebutkan bahwa frekuensi pemberian makan yang dilakukan sebagian besar informan paling sering 2 kali perhari, bahkan hanya 1 kali jika sedang bepergian. Keadaan serupa digambarkan dalam penelitian Makmur (2008), dimana frekuensi makan anak lebih sering 2 kali sehari atau makan jika lapar saja. Dalam penelitian tersebut digambarkan pula bahwa anak yang kurang gizi makan hanya 2 kali perhari dan jarang meminum susu.

Penyebab ibu memberikan makan hanya 3 kali perhari kepada anaknya dapat disebabkan karena kurangnya pengetahuan frekuensi makan yang baik untuk balita. Hal ini didasarkan pada jawaban informan yang ketika ditanya berapa kali anak makan, ibu menjawab "makannya bagus, 3 kali sehari". Dalam konteks ini, ibu mengira jika anak sudah diberikan makan 3 kali, maka itu sudah cukup karena mengikuti kebiasaan orang dewasa.

Peran kader atau petugas kesehatan seperti bidan atau TPG dalam memberikan pengetahuan makan yang baik kepada ibu balita sangat diperlukan. Hal ini karena ketika wawancara mendalam didapatkan jawaban yang sangat baik oleh salah satu informan utama, dimana ibu tersebut mengatakan "beri makan anak sedikit, tapi sering, kata bidannya gitu". Hal yang menyebabkan ibu mengetahui informasi tersebut karena ia selalu rutin datang ke posyandu dan banyak bertanya kepada kader atau bidan yang ada. Namun dalam praktiknya, ibu tersebut memberikan anak hanya 3 kali perhari. Pemberian makan anak 3 kali tersebut mungkin disebabkan karena susahnya anak makan, jadi ibu hanya memberikan frekuensi seperti pada umumnya yaitu 3 kali perhari.

Dalam hal porsi makan yang diberikan, didapatkan gambaran bahwa 3 anak memilki masalah sulit makan. Ketika makan, ketiga anak tersebut mengkonsumsi tidak lebih dari 5 suap. Namun, terdapat 1 anak yang sangat suka makan, sekali makan anak tersebut dapat menghabiskan 1 centong nasi atau lebih. Hal tersebut didapatkan dari hasil wawancara kepada informan utama dan informan keluarga. Ketika observasi, terdapat anak yang lebih sering makan sendiri. Yang menjadi masalah, walaupun ibu memberikan makanan yang terlihat cukup dari segi porsi, anak ketika makan terlihat mengacak-acak makanan dan tidak menghabiskannya. Jumlah yang dikonsumsi berdasarkan pengamatan sekitar 2 sampai 4 sendok makan saja. Jika dilihat dari anjuran UNICEF dalam booklet pesan utama pemberian makan bayi dan anak, porsi sebagian besar anak termasuk kurang. 
UNICEF menganjurkan banyaknya makanan untuk anak 12-24 bulan yaitu meningkatkan jumlahnya menjadi $3 / 4$ cangkir atau sekitar $250 \mathrm{ml}$.

Hal diatas sejalan dengan penelitian Verival $(2010)^{8}$ yang menggambarkan porsi makan 3 dari 4 balita yang tidak mengalami peningkatan status gizi sebanyak 2 sendok makan atau sekitar 10 gram. Meskipun demikian, terdapat 1 anak yang sering diberikan nasi sebanyak 1 centong atau sekitar 100 gram. Kurangnya asupan makan anak mungkin disebabkan karena anak sulit makan. Sulitnya anak makan mungkin disebabkan karena penyajian makanan yang kurang menarik.

Selain itu, variasi makanan yang kurang bagi anak mungkin menjadi faktor lain yang mempengaruhi sulitnya anak makan. Dalam memberikan makanan kepada anak variasi sangat diperlukan. Hal ini dilakukan agar anak tidak bosan sehingga dapat menghindarkan anak dari kesulitan makan pada usia berikutnya [15]. Variasi makanan sangat diperlukan dalam memberikan makan kepada anak karena tidak ada satu jenis makanan pun yang mengandung semua zat gizi yang diperlukan tubuh [16].

Hampir semua anak memiliki kebiasaan jajan seperti chiki, permen, es, biskuit, wafer, roti, ataupun jajanan yang dijual oleh penjual keliling. Hasil tersebut diperoleh dengan cara wawancara kepada informan utama. lbu mengatakan anak jajan diawasi, tetapi karena jika tidak diberi anak akan menangis atau tetap meminta, maka ibu tetap memberikannya terkadang juga tidak. Berdasarkan observasi ada 1 anak yang diberi jajan oleh teman-temannya seperti permen. Ketika mewawancarai ibu, ibu menjawab memang benar anak sering diberi makanan oleh temannya.

Hasil diatas sejalan dengan penelitian yang dilakukan oleh Makmur (2008) [11] yang mengatakan bahwa semua anak suka jajan, dan semua ibu balita menuruti kemauan anak untuk jajan dengan alasan untuk menghindari anak menangis. Kebiasaan jajan pada anak dalam penelitian ini mungkin menjadi penyebab lain anak susah makan. Kebiasaan jajan pada anak merupakan salah satu faktor penghambat dalam upaya perbaikan gizi [11]. Moehyi dalam Veriyal (2010) mengatakan bahwa kebiasaan jajan pada anak mempunyai kelemahan, jajanan biasanya banyak mengandung hidrat arang [8]. Jika anak terlalu sering jajan maka anak akan kenyang, hal ini menyebabkan anak tidak mau makan nasi, kalaupun mau jumlahnya sedikit. Selain itu kebersihan jajanan sangat diragukan. Jika keinginan anak tidak dituruti anak akan menangis dan menolak untuk makan. Sedangkan dari segi pendidikan, kebiasaan jajan tidak dapat dianggap baik, apalagi jika anak sudah diberikan uang untuk membeli makanannya sendiri.

Kunci keberhasilan dalam menanamkan pola makan yang baik pada anak tergantung pada pengetahuan dan pengertian ibu tentang gizi. Anak akan mencontoh makan makanan yang dimakan oleh orang tua dan orang terdekat yang ada di sekitarnya. Pengetahuan yang rendah pada ibu mengakibatkan ibu kurang perhatian terhadap gizi anaknya, membiarkan kebiasaan jajan dan membiarkan anak memilih makanan sesuai keinginannya. Hal yang perlu dilakukan ibu dalam mengatasi masalah ini adalah membuat menu makanan harian yang bervariasi dan tetap mengakomodir keinginan anak namun tentu mampu memenuhi kebutuhan gizi harian anak [11].

Salah satu faktor yang mempengaruhi pola asuh pemberian makan pendamping ASI dalam penelitian ini yaitu pengetahuan. Pengetahuan ibu kurang dari variasi, frekuensi dan porsi makanan yang dianjurkan. Namun, ketika terdapat ibu yang memilki pengetahuan baik dalam beberapa aspek pemberian makan, karena kondisi 
ekonomi yang kurang ibu tidak bisa berbuat banyak. Selain itu sebagian besar anak dalam penelitian ini sulit untuk makan. Faktor kemauan ibu untuk mengatasi masalah tersebut terlihat kurang baik, dimana tidak ada cara yang dilakukan ibu untuk mengatasi masalah tersebut.

\section{SIMPULAN}

Pola asuh pemberian makanan pendamping ASI masih kurang dari variasi, porsi dan frekuensi pemberiannya. Variasi yang diberikan, biasanya anak lebih sering makan dengan nasi dan satu macam lauk seperti telur. Porsi untuk anak tidak sesuai yang dianjurkan karena anak sulit untuk makan, jika dihitung berdasarkan suapan, banyaknya hanya 2-5 suapan saja. Frekuensi makan yang diberikan kepada anak banyaknya 2-3 kali pemberian makanan dalam sehari. Padahal frekuensi makan yang baik untuk anak adalah sedikit tetapi sering karena perut anak yang masih kecil. Kebiasaan jajan anak yang berbarengan atau tidak diatur dengan waktu makan dan mengkonsumsi makanan yang lebih bayak mengandung karbohidrat dan perasa seperti vetsin menjadi masalah karena orang tua terpaksa menuruti kemauan anak untuk menghindari anak menangis.

Peran aktif ibu atau pengasuh sangat dibutuhkan dalam pemberian makan kepada anak. Ibu atau pengasuh dianjurkan untuk rutin datang ke posyandu dan menanyakan kepada kader ataupun petugas kesehatan tentang pemberian MP-ASI yang baik untuk anak terutama dari segi porsi, frekuensi dan variasi. Selain itu petugas kesehatan harus selalu melakukan pendampingan pada balita stunting agar dapat mendapatkan derajad kesehatan yang optimal.

\section{UCAPAN TERIMAKASIH}

Penulis mengucapkan terimakasih kepada Kepala desa Cipadang, Ka. UPT. Puskesmas
Gedong Tataan atas bantuan sehingga terlaksana pengumpulan data, selanjutnya kepada unit penelitian dan pengabdian kepada masyarakat Poltekkes Tanjung Karang serta tim reviewer dan tim redaksi Jurnal Proteksi Kesehatan Poltekkes Kemenkes Riau.

\section{DAFTAR PUSTAKA}

[1] Kemenkes RI. (2011). Permenkes RI No. 1995/Menkes/SK/IX/2010 tentang Standar Antropometri Penilaian Status Gizi Anak. Jakarta : Dirjen Bina Gizi dan Kesehatan

[2] UNICEF. (2013). Improving Child Nutrition, The Achievable Imperative For Global Progress. United Nations Children's Fund (UNICEF) New York.

[3] MCA-Indonesia. (2014). Proyek Kesehatan dan Gizi Berbasis Masyarakat untuk Mengurangi Stunting. http://mcaindonesia.go.id/compactprogram/kesehatan/

[4] Kemenkes RI. (2014). Pokok-pokok Hasil Riskesdas Provinsi Lampung 2013. Badan Penelitian dan Pengembangan Kesehatan Kemenkes RI, Jakarta.

[5] Fitriana, Hartoyo, Nasution \& Amini. (2007). Hubungan pola asuh, status gizi dan status kesehatan anak balita di wilayah program warung anak sehat (WAS) Kabupaten Sukabumi. Skripsi. Fakultas Ekologi Manusia IPB.

[6] Sab'atmaja, S., Khomsan, A., A., \& Tanziha, I. (2010). Analisis Determinan Positif Deviance Status Gizi Balita di Wilayah Miskin Dengan Prevalensi Kurang Gizi Rendan dan Tinggi. Jurnal Gizi dan Pangan, Juli 2010.

[7] Lubis \& Khairida Afni. (2010). Analisis Kualitatif Pola Asuh Balita Gizi Buruk di Kecamatan Pasar Minggu dan Kecamatan Jagakarsa Kota Administrasi Jakarta Selatan Tahun 2010. Skripsi. FKIK UIN Syarif Hidayatullah Jakarta. 
[8] Veriyal, N. (2010). Analisis Pola Asuh lbu Terhadap Balita Kurang Energi Protein (KEP) yang Mendapat PMT-P di Puskesmas Pagedangan Kab. Tangerang Tahun 2010, Skripsi. UIN Syarif Hidayatullah Jakarta

[9] Akhmadi. (2009). Pengalaman Keluarga Merawat Anak Usia Sekolah dengan Obesitas yang Bersekolah di SD Kota Yogyakarta. Tesis. Program Studi IImu Keperawatan FIK UI

[10] Miles, M.B., \& Huberman, A.M. (1994). Qualitative Data Analysis. SAGE Publication. United States of America

[11] Makmur \& Asmilia. (2008). Analisis Pelaksanaan Usaha Perbaikan Gizi Balita di Posyandu Terintegrasi Taman Posyandu di Desa Kedawung Kab. Kebumen Tahun 2008. Tesis. FKM UI

[12] Proverawati, Atikah, Asfuah \& Siti. (2009). Buku Ajar Gizi untuk Kebidanan. Jakarta: Nuha Medika

[13] Nurhayati, Ai. \& Sudewi. (2009). Reka Cipta Menu Balita Sebagai Upaya Mengatasi Sulit Makan dan Kurang Gizi Pada Balita. Media Pendidikan, Gizi dan Kuliner, Vol. 1, Oktober 2009

[14] Soetardjo \& Susirah. (2011). Gizi Seimbang dalam Daur Kehidupan Gizi Anak. Jakarta : PT Gramedia Pustaka Utama

[15] Auliana \& Rizqie. (2011). Gizi Seimbang dan Makanan Sehat untuk Anak Usia Dini. Diakses dari http://staff.uny.ac.id/sites/default/file s/pengabdian rizqie-auliana-dramkes/gizi-seimbang-dan-makanansehat-untuk-anak-usia-dini.pdf

[16] Muharyani \& Putri Widita. (2012). Hubungan Praktik Pemberian Makan dalam Kelvarga dengan Kejadian Sulit Makan pada Populasi Balita di Kota Batu Kota Palembang. Tesis. FIK UI 